\title{
Quality of life in neighbourhoods undergoing renewal: Evidence from Mashhad, Iran
}

Urban decay is one of the most critical challenges in urban development, whereby old urban districts fall into decrepitude and face serious social, economic, and physical problems. Governments thus implement renewal projects to revitalize physical and functional structures, restore socioeconomic capacity, and improve residents' quality of life. However, ignoring the complex nature of intervention in old urban areas may have undesirable consequences, including an additional decline in residents' quality of life. This article assesses residents' quality of life in neighbourhoods undergoing renewal, supported by experience from Mashhad, Iran. Using a mixed-methods design, it combines quantitative and qualitative methods of impact assessment, including questionnaires, semi-structured interviews, georeferenced data, and direct observation. The results show that a lack of sustainable financing for the Samen Renewal Project has had undesirable physical, sociocultural, and economic effects in the historical district of Mashhad and significantly reduced residents' quality of life due to focusing on the interests of tourists, pilgrims, and especially private developers.

Keywords: quality of life, urban transformation, urban renewal, urban decay, Iran 


\section{Introduction}

Conventional urban development has faced complex challenges in recent years, ranging from the phenomenon of shrinking cities to physical decay, environmental risk management, heritage preservation, security, transport, health, and social inequality (El Din et al., 2013; Marra et al., 2016). Urban decay is one of the most critical challenges in urban development, whereby by a previously functioning city, or part of a city, falls into decrepitude and faces serious problems such as depopulation, abandoned buildings and infrastructure, high unemployment, increased poverty, a desolate cityscape, crime, and low living standards and quality of life (Dale, 1999; Deng \& Ma, 2015; Andersen, 2019). This is particularly crucial in unplanned traditional core areas of towns and cities, specifically in developing countries, in which traditional core areas are most often the oldest parts of cities (Ibem, 2013). These traditional core areas are typically marginalized during urban development and face challenges related to decay, dwindling economic function, dilapidation, and migration to better and more modern areas (Munoth et al., 2013). As these old urban areas fall into decline, they not only lose their ability to satisfy residents' needs, but also pose social, cultural, and economic challenges for the city (Dale, 1999).

However, international experience has shown that investment in historical cores can contribute to urban revitalization, tourism, job creation, reversing fiscal drain, increased liveability, social cohesion, and reduced crime (Bigio \& Licciardi, 2010). Thus, governments are enthusiastic to intervene in these traditional core areas through urban renewal projects (Bianchini \& Parkinson, 1994; Leary \& McCarthy, 2013). These large-scale interventions generally seek to reverse decline by improving physical structure, social inclusion, welfare services, and more importantly but sometimes elusively - the economy of those areas (Leary \& McCarthy, 2013; Roberts et al., 2016). Thus, urban renewal can be an effective tool for promoting sustainable urban transformation and enhancing the macroand micro-level quality of life if the principles of encouraging participation, building community character, advancing equity, improving the environment, and invigorating the economy are observed (Ng, 2005; von Hoffman, 2008; McCormick et al., 2013). This can be achieved through various governance mechanisms derived from two rather different orientations: the tradition of universalism and the neo-liberal worldview of urban problems (McCarthy, 2007; Leary \& McCarthy, 2013). However, lack of an integrated approach in the perception and implementation of such renewal projects may negatively impact residents' quality of life by exacerbating unsustainable urban changes such as increases in property values and the cost of living, social exclusion, gentrification, and displacement of poorer residents (Atkinson, 2000; Bacqué et al., 2011).
Although the relationship between quality of life and various urban characteristics such as socioeconomic status (Mielck et al., 2014; Rokicka \& Petelewicz, 2014; Bielderman et al., 2015), environmental factors (Lo \& Faber, 1997; Li \& Weng, 2007), population density (Cramer et al., 2004), household density (Carnahan et al., 1974), amenities, and economic performance (Deller et al., 2001) has been widely addressed in recent decades, assessing the quality of life in residential neighbourhoods during implementation of renewal projects has rarely been examined, specifically at a local scale. Because several variables of quality of life, such as population factors, infrastructure conditions, and environmental factors, can be deeply affected by renewal projects (Johansson, 2002; Li \& Weng, 2007; Lee, 2008), investigating the quality of life in neighbourhoods being transformed by such projects could offer the research community a fresh perspective.

The traditional core district of Mashhad, Iran, has been experiencing the largest and longest-running government-run renewal project in Iran for twenty-five years. The Samen Renewal Project primarily aims to improve residents' quality of life and raise the performance and competitiveness of the tourism industry in the central district of the city through largescale physical intervention. Such intervention in the historical district of the city could have a wide range of impacts and consequences, one of the most important of which is changing the quality of life. This article examines the central district of Mashhad as a laboratory for assessing the quality of life in neighbourhoods being transformed by large-scale renewal projects.

\section{Methods}

Renewal projects can have various quantitative and qualitative impacts, and so a combination of quantitative and qualitative methods is necessary to assess these impacts. This study uses a mixed-methods sequential explanatory design, which involves collecting and analysing quantitative and qualitative data in two consecutive phases within one study. This method is used to explain and interpret quantitative results through a qualitative analysis (Creswell, 1999). A combination of qualitative and quantitative methods of impact assessment was considered following the principles of participatory assessment (Roche, 1999; Morris et al., 2011; Catley et al., 2014; Forouhar, 2016).

To assess the quality of life in the traditional core district of Mashhad and the impacts and consequences of the Samen Renewal Project, this article uses a conceptual model of quality of life (Figure 1) derived from various literature (Day, 1987; Cummins, 1996; Musschenga, 1997; Seik, 2001; Johans- 


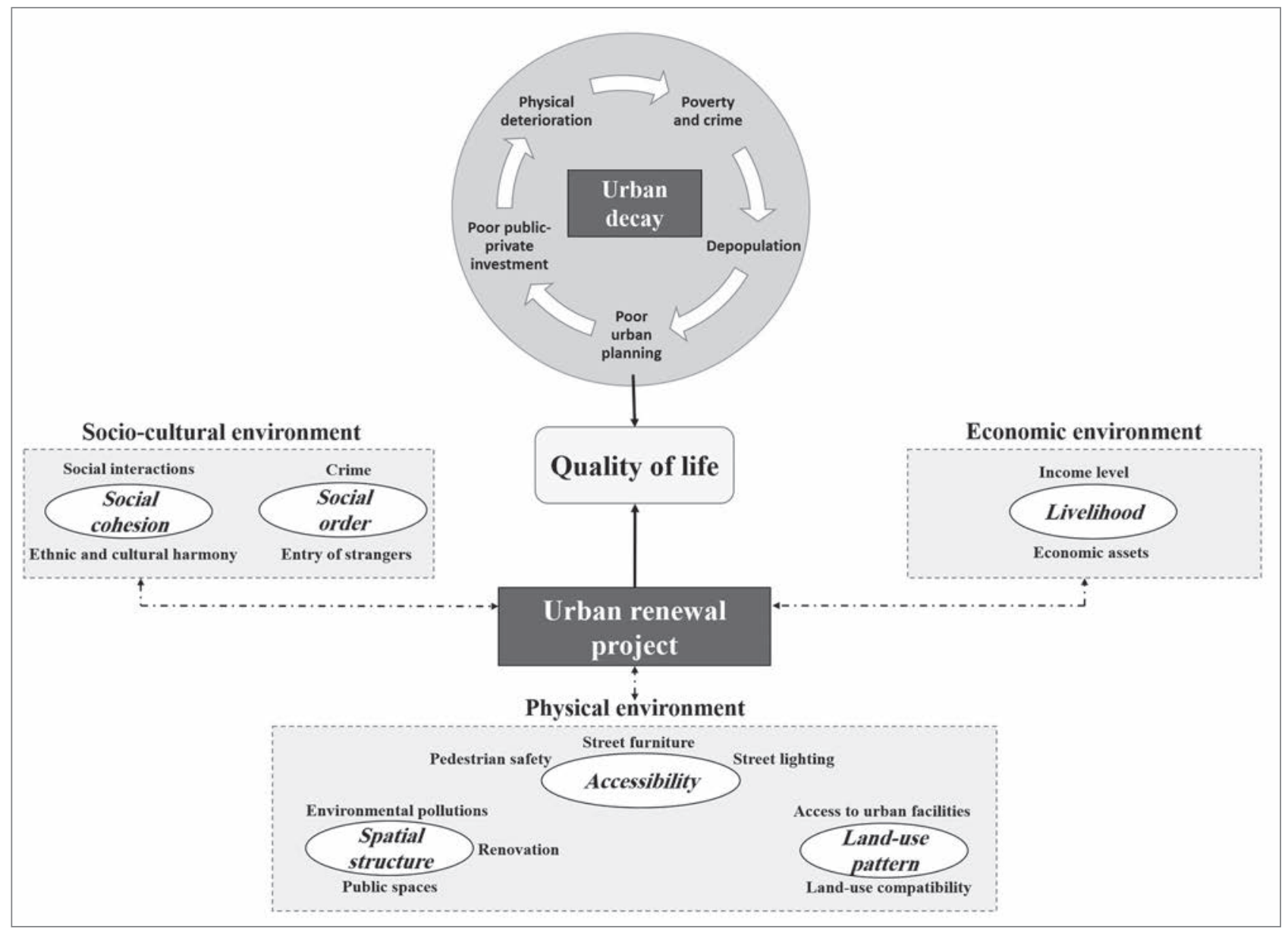

Figure 1: Conceptual model of quality of life (illustration: Amir Forouhar).

son, 2002; Costanza et al., 2007; Marans \& Stimson, 2011). According to this model, urban decay is a sociological process in which a previously functioning city, or part of a city, falls into disrepair and decrepitude. It may feature poor urban planning and development policies, economic stagnation, abandoned buildings and infrastructure, high local unemployment, increased poverty, crime, depopulation, and low overall living standards and quality of life (Dale, 1999; Deng \& Ma, 2015; Andersen, 2019). Renewal projects generally attempt to reverse that decline by improving the physical structure, sociocultural environment, and especially the economy of those areas. However, the precise emphasis may vary according to context (Ibem, 2013; Leary \& McCarthy, 2013; Tallon, 2013; Roberts et al., 2016; Andersen, 2019).

This study used questionnaires, semi-structured interviews, georeferenced data, and direct observation. To determine the sample size for questionnaires, IBM SPSS Sample Power (version 3.0.1) was used to consider a maximum probability of $5 \%$ for error type I and 20\% for error type II (minimum test power of $80 \%$ ), and a minimum effect size of 0.2 , which calculated the sample size as 265. Based on theoretical saturation, the semi-structured interviews included thirty-five local residents, twenty local shopkeepers, ten tourists, and five real estate agencies. The sampling method was random sampling with a random walk technique (RWT). The RWT is a random sampling method in which the number of paces between sample points is determined by random numbers, usually drawn from random-number tables, and from each sample point a right-angle turn determines the direction of the next point (Roche, 1999; Forouhar \& Hasankhani, 2018).

The questionnaires and interviews asked about residents' satisfaction with the physical, sociocultural, and economic circumstances of their living environment, their perception of change, and its causes in the neighbourhood. Applying participatory assessment methods such as trend analysis and historical timelines (Roche, 1999; Morris et al., 2011; Catley et al., 2014; Forouhar, 2016), the respondents were asked to discuss some major trends of events in their neighbourhoods over time, and to then recall how those changes had occurred, thereby reconstructing history by adding other events and the implementation processes in the Samen Renewal Project. To analyse the qualitative data, all recorded interviews used an open coding system to label concepts, and define and develop categories based on their properties and dimensions. 


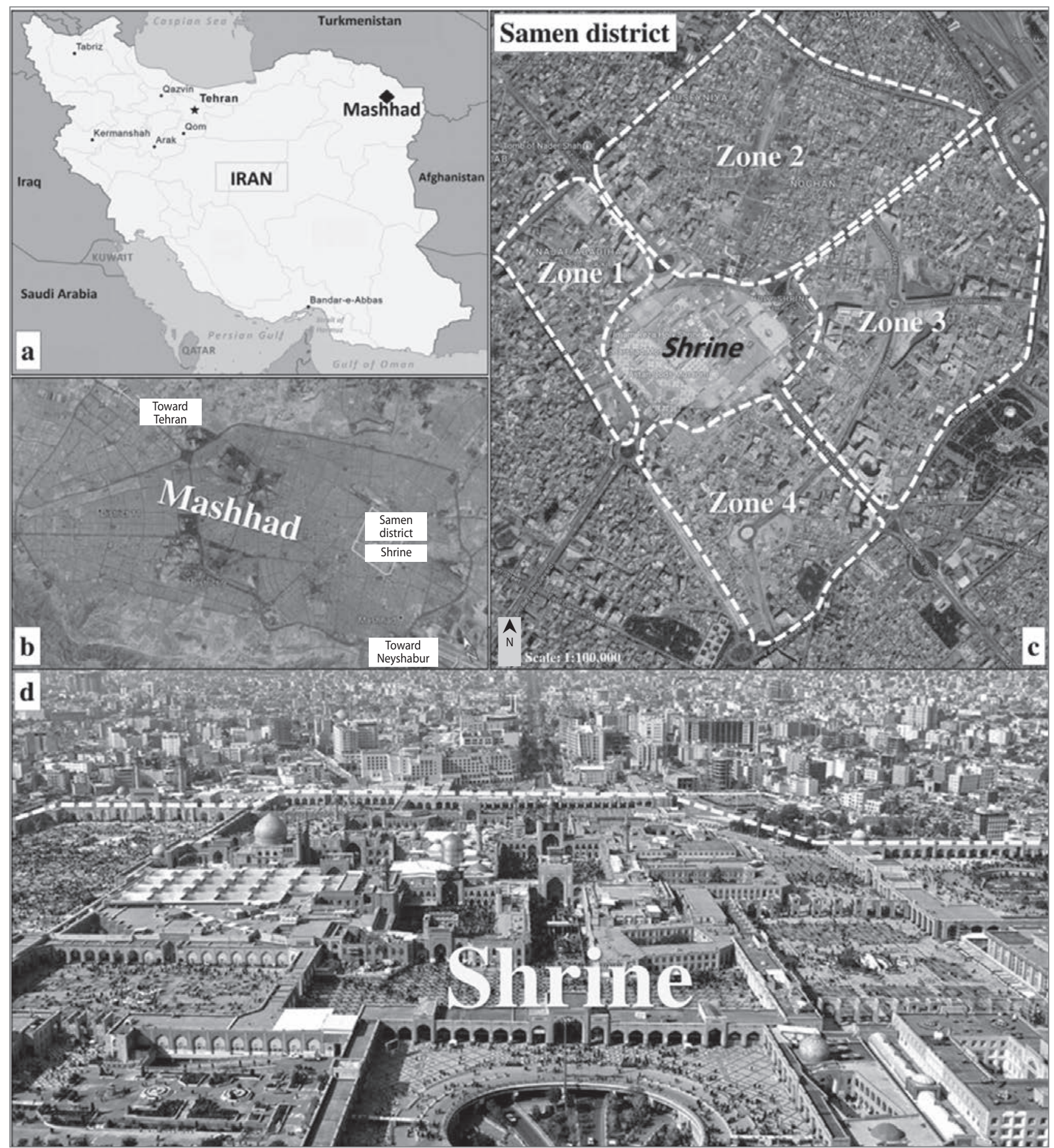

Figure 2: a) location of Mashhad in Iran (illustration: authors); b) Mashhad; c) Samen district of Mashhad and the study area (source: Map data, 2020); d) the shrine (photo: Mohammad Khoshneshin, ILNA News Agency).

\section{Case study}

Mashhad is the second-largest city in Iran and the second-largest Shia holy city in the world. It attracts more than thirty million tourists and pilgrims every year, many of whom come to pay homage to the Imam Reza shrine dedicated to the eighth Shi' ite imam (Mashhad Municipality, 2017). This city has been a magnet for pilgrims and tourists since medieval times (Kaf- ashpor et al., 2018). Mashhad experienced population growth after the Anglo-Soviet invasion of Iran in 1941 because of relative insecurity in rural areas, and the rapid increase in population continued in the following years thanks to an increase in Iranian oil revenues, the decline of the feudal social model, agrarian reform, religious attractions, and the development of the healthcare system (Kheyroddin et al., 2014; Abrahamian, 2018; Rabbani et al., 2018). 
Table 1: Satisfaction of local residents with their living environment.

\begin{tabular}{|c|c|c|c|c|c|c|c|}
\hline \multirow[t]{2}{*}{ Component } & \multirow[t]{2}{*}{ Domain } & \multirow[t]{2}{*}{ Indicator } & \multicolumn{5}{|c|}{ Satisfaction (\%) } \\
\hline & & & 1 & 2 & 3 & 4 & 5 \\
\hline \multirow{8}{*}{$\begin{array}{l}\text { Physical enviro- } \\
\text { nment }\end{array}$} & \multirow{3}{*}{ Accessibility } & Street lighting & 35.1 & 31.3 & 28.1 & 3.7 & 1.8 \\
\hline & & Street furniture & 31.3 & 38.2 & 21.8 & 5.8 & 2.9 \\
\hline & & Pedestrian safety & 26.4 & 37.5 & 26.3 & 6.1 & 3.7 \\
\hline & \multirow{3}{*}{ Spatial structure } & Renovation & 30.5 & 39.3 & 21.9 & 7.2 & 1.1 \\
\hline & & Public spaces & 38.2 & 34.2 & 20.1 & 5.2 & 2.3 \\
\hline & & Environmental pollution & 28.7 & 43.3 & 24 & 4.0 & 0.0 \\
\hline & \multirow{2}{*}{ Land-use pattern } & Access to urban facilities & 29.3 & 40.0 & 26 & 4.0 & 0.7 \\
\hline & & Land-use compatibility & 22.9 & 51.1 & 19 & 4.0 & 3.0 \\
\hline \multirow{4}{*}{$\begin{array}{l}\text { Sociocultural envi- } \\
\text { ronment }\end{array}$} & \multirow{2}{*}{ Social order } & Crime & 38.0 & 41.3 & 16.7 & 4.0 & 0.0 \\
\hline & & Entry of strangers & 32.4 & 41.5 & 21.3 & 4.7 & 0.1 \\
\hline & \multirow{2}{*}{ Social cohesion } & Social interactions & 15.4 & 36.2 & 36.7 & 8.7 & 3.0 \\
\hline & & Ethnic and cultural harmony & 24.9 & 33.2 & 29.3 & 9.2 & 3.4 \\
\hline \multirow{2}{*}{$\begin{array}{l}\text { Economic enviro- } \\
\text { nment }\end{array}$} & \multirow{2}{*}{ Personal livelihood } & Income level & 47.3 & 34.7 & 14.7 & 3.3 & 0.0 \\
\hline & & Economic assets & 41.3 & 37.2 & 17.2 & 2.5 & 1.8 \\
\hline
\end{tabular}

Note: 1 = completely dissatisfied, $2=$ somewhat dissatisfied, $3=$ neither satisfied nor dissatisfied, $4=$ somewhat satisfied, $5=$ completely satisfied.

Table 2: Descriptive statistics for quality of life in the study area.

\begin{tabular}{lllllllllll}
\hline \multicolumn{10}{l}{ Descriptive statistic } & \multicolumn{1}{l}{} \\
\hline & $M$ & Lower & Upper & Mdn & Mo & Var & SD & Min. & Max. & Ra \\
\hline Total & 3.2100 & 2.8866 & 3.5182 & 3.0000 & 2.00 & 3.567 & 1.83014 & 1.00 & 9.00 & 8.00 \\
\hline Men & 4.1432 & 3.6581 & 4.3648 & 4.0000 & 3.00 & 3.003 & 1.67712 & 2.00 & 9.00 & 7.00 \\
\hline Women & 2.2768 & 2.0148 & 2.7400 & 2.0000 & 2.00 & 2.651 & 1.57602 & 1.00 & 8.00 & 7.00 \\
\hline
\end{tabular}

Table 3: One-sample $t$-test for quality of life in the study area.

\begin{tabular}{llllll}
\hline$t$-test statistic & & & & \\
\hline$t$ & $d f$ & Sig. (two-tailed) & Mean difference & Lower & Upper \\
\hline-12.670 & 146 & .000 & -2.19000 & -2.5132 & -1.8868 \\
\hline
\end{tabular}

Over the past decades, the central district of Mashhad, which includes the historical core of the city around the shrine (the Samen district), was marginalized during urban development and faced serious challenges related to physical and functional decay. In 1965 an important urban renewal project for the surroundings of the shrine was proposed by the government to replace the dilapidated buildings and infrastructure that surrounded the shrine. Although the project was officially approved in 1968 and some neighbourhoods were demolished, the project was abandoned after the Iranian revolution in 1978 (Sarkheyli et al., 2016; Kafashpor et al., 2018; Forouhar \& Forouhar; 2020). However, the shrine and its related economic potential for tourism as well as growing sociocultural, economic, and political challenges in the traditional core of Mashhad encouraged the government to intervene in 1992 through a renewal mega-project: the Samen Renewal Project. The project primarily aimed to improve residents' quality of life, meet the needs of tourists and pilgrims, improve urban services, and upgrade the performance and competitiveness of the central district of Mashhad to achieve a global and regional position (Hosseyni, 2008; Sarkheyli et al., 2016). Today, the Samen Renewal Project is the largest and longest-running government-run renewal project in Iran; it covers approximately 366 hectares and is run by the Samen Renovation Organization Figure 2). Because this renewal mega-project has only achieved $50 \%$ of its goals in about twenty-five years, it has turned into one of the most controversial mega-projects in Iran and resulted in serious challenges to Mashhad's urban management.

\section{Results}

In the statistical sample, 140 men (52.8\%) and 125 women (47.2\%) responded to the questionnaire (sex ratio: 1.12). The respondents' average age was thirty-four (range: fifteen to seventy-eight). Forty-nine per cent of the sample population was 
Table 4: Correlation between components/domains with quality of life in the study area.

\begin{tabular}{lll}
\hline & Quality of life & \\
\hline Physical environment & Pearson coefficient & Sig. (two-tailed) \\
\hline Accessibility & $0.755^{*}$ & .000 \\
\hline Spatial structure & $0.696^{*}$ & .000 \\
\hline Land-use pattern & $0.719^{*}$ & .000 \\
\hline Sociocultural environment & $0.657^{*}$ & .000 \\
\hline Social order & $0.751^{*}$ & .000 \\
\hline Social cohesion & $0.746^{*}$ & .000 \\
\hline Economic environment & $0.625^{*}$ & .000 \\
\hline Livelihood & $0.624^{*}$ & .000 \\
\hline
\end{tabular}

Note: ${ }^{*} p=.01$.

non-native, reflecting the high degree of immigration into the study area. In addition, $37.3 \%$ of the respondents had been living in the area for less than five years and $69.1 \%$ less than ten, which reflects evacuation of the neighbourhood by older local residents. Table 1 shows local residents' satisfaction with the physical, sociocultural, and economic circumstances of their living environment.

Tables 2 and 3 also indicate that, on average, the sample population ranked their quality of life at 3.21 on a scale from 1 to 10 . The respondents assessed their quality of life as lower than the possible median value (5.50). The comparison of subjective quality of life by respondents' sex shows that women's average score for quality of life was lower than men's average score. In addition, a one-sample $t$-test indicates that the quality of life is also lower than the possible median value with a confidence level of $99 \%$. The Pearson correlation coefficient shows that the physical environment has the strongest correlation with the subjective quality of life among the components in the study area. With increasing satisfaction with the physical environment, residents' quality of life increases, and vice versa. In addition, among the domains, social order correlates most strongly with residents' quality of life (Table 4).

\subsection{Physical impacts}

One of the main goals of the Samen Renewal Project was to provide residents and pilgrims with access to commercial, recreational, and accommodation centres, and to the shrine throughout the historical core of Mashhad. The construction of two boulevards and a few service routes around the new commercial-residential buildings are the main activities of the project (Samen Renewal Organization, 2002). The construction of these new roads has led to the large-scale destruction of old routes in this district. As a result, residents and pilgrims have been forced to use alternative and temporary routes for two decades. More than $65 \%$ of the respondents were somewhat or completely dissatisfied with the lighting of pedestrian routes. Only $2.9 \%$ were completely satisfied with urban furniture, and more than two-thirds were somewhat or completely dissatisfied with pedestrian safety.

A field survey indicates that only the service routes to the new commercial-residential buildings (shopping malls, luxury hotels, and other accommodation) are well designed and well equipped with proper lighting and furniture. In contrast, temporary routes (which include most of the pedestrian routes in the district) suffer from a lack of street lighting, facilities especially for vulnerable groups, and well-designed and harmonious urban furniture (Figure 3). In addition, temporary routes lack necessary pedestrian safety precautions for traffic. The Samen Renovation Organization has prioritized access to income-generating commercial-residential complexes and has ignored improving temporary local routes, which is considered costly. "The renewal project has meant nothing but destruction for the residents of this neighbourhood. Many local streets have been destroyed to create access to commercial centres, hotels, and hostels, and the authorities have opened temporary pedestrian routes that are difficult to walk on at night even with a flashlight" (38-year-old male resident).

The Samen Renewal Project was intended to improve the quality of the environment through constant renovation, increasing well-equipped public spaces, and reducing environmental pollution. More than $60 \%$ of the respondents were somewhat or completely dissatisfied with this expectation. The number of construction permits issued in the Samen district from 2013 to 2015 was very small proportionate to the entire city: sixty permits were issued in 2013 ( $0.8 \%$ of the entire city), nineteen in 2014 ( $0.03 \%$ of the entire city), and nineteen in 2015 ( $0.5 \%$ of the entire city; Samen Renewal Organization, 2002). Although the number of permits issued is negligible, they cover a large area; the average area of each of 


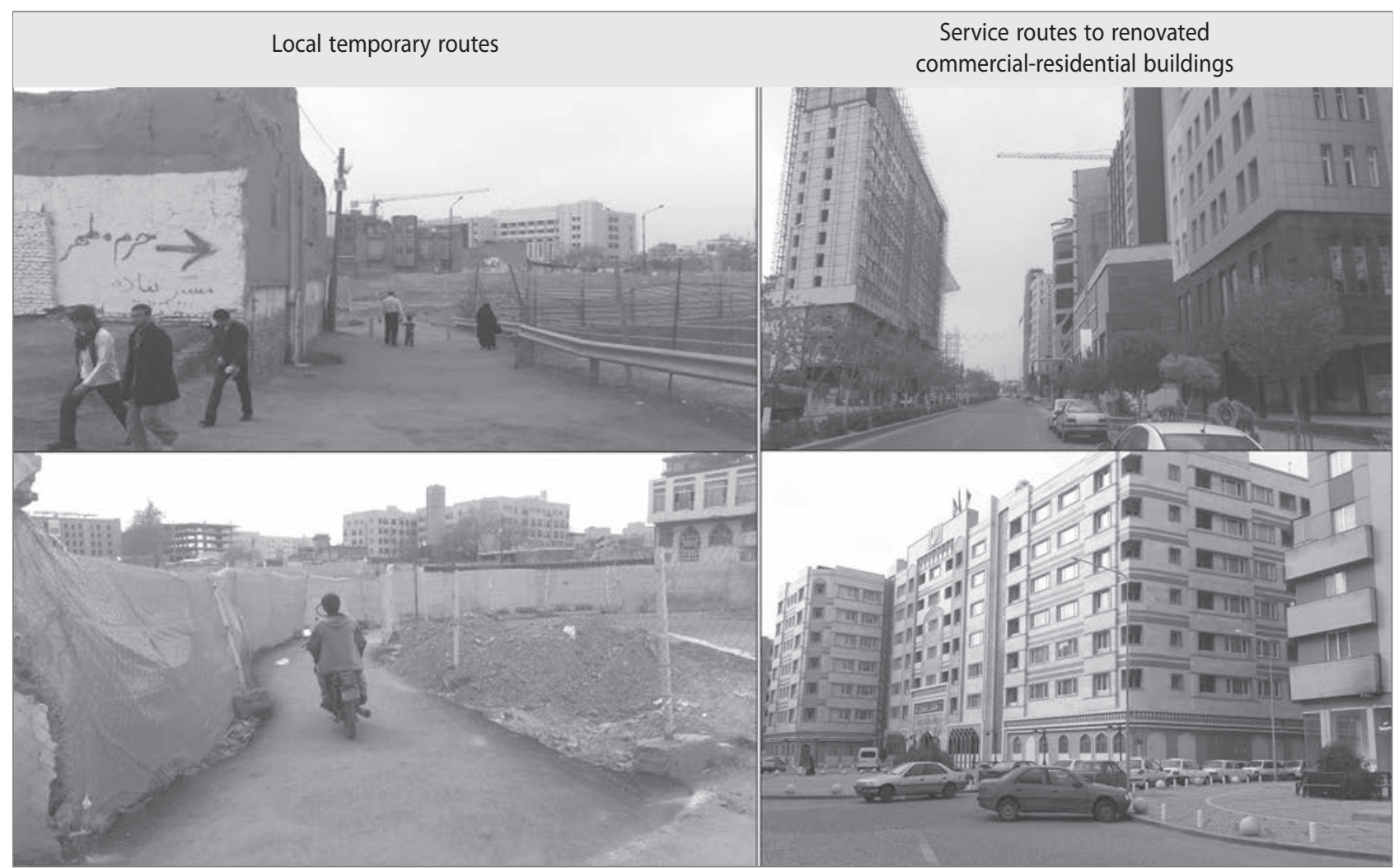

Figure 3: Comparison between temporary local routes and service routes to new commercial-residential buildings (photo: Navid Forouhar).

the permits in 2013 was $8,640 \mathrm{~m}^{2}$, in 2014 it was $4,156 \mathrm{~m}^{2}$, and in 2015 it was $6,039 \mathrm{~m}^{2}$. The statistics show that construction permits in the Samen district have been issued for large-scale residential and commercial projects, and not for local residents' properties. This reflects the commercialization of residential areas surrounding the shrine in terms of generating revenue rather than improving residents' quality of life. Interviews with real estate agencies also show that the execution of the project was an important factor in the decline of small-scale renovation by residents. As soon as the project was launched, the Samen Renovation Organization suspended construction permits and prohibited locals from selling their properties. As a result, private construction and small-scale renovation stopped immediately. Residents could only sell their properties at a low price to the organization or wait for an uncertain future (City Council of Mashhad, 2016).

The field survey shows that new spaces resulting from the destruction of old buildings are currently used as parking lots or have become unsafe spaces. A major justification for the project was the lack of sanitation in the district (Samen Renewal Organization, 2002), but the interviews and field surveys indicate that environmental pollution has been significantly exacerbated because the demolished buildings have turned into dumps for household and construction waste. In 2016, the Mashhad Health Organization ranked the Samen district first in an outbreak of cutaneous leishmaniasis. The long-term

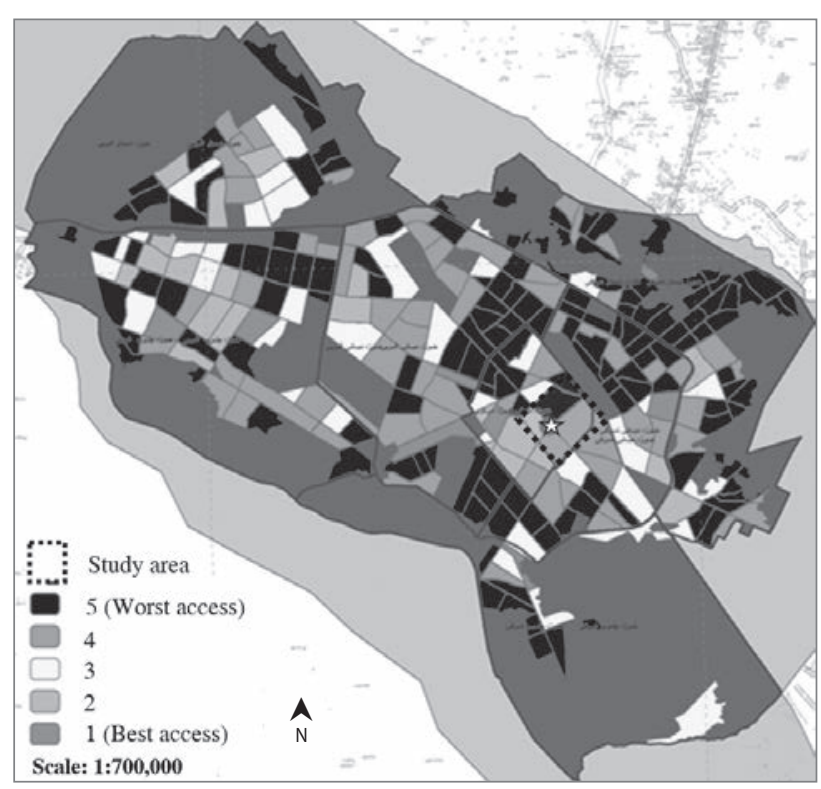

Figure 4: Access to urban facilities and public services in Mashhad (illustration: Navid Forouhar; source: Mashhad Municipality, 2017).

construction of commercial-residential buildings and roads has also led to noise pollution. This pollution can affect residents' physical and mental health, and eventually increases the incidence of disease. 


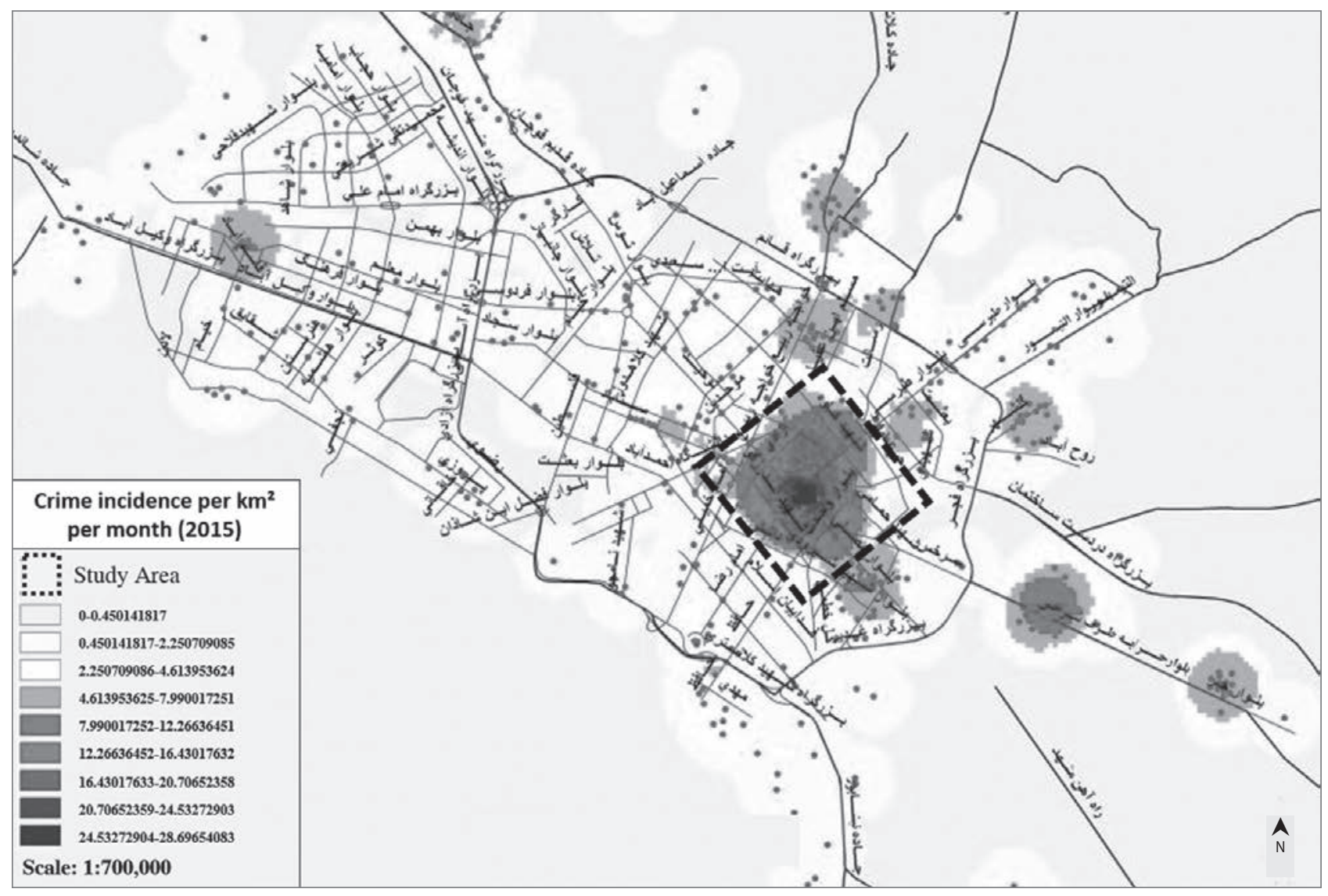

Figure 5: Crime incidence in Mashhad (source: Mashhad Police Department, 2016).

The results of the questionnaires demonstrate that the Samen Renewal Project failed to maintain a balance between the needs of residents and pilgrims. Nearly two-thirds of the respondents were somewhat or completely dissatisfied with their access to urban facilities and the compatibility of activities. In 2008, due to the slow progress of the project, the authorities decided to attract investors for financing and accelerating it. The organization made important changes in the proposed land-use plan. Based on these changes, the proposed residential parcels were converted into large-scale commercial-residential properties. Consequently, many houses were purchased at a low price using legal leverage. These properties were then aggregated and converted into large lots to build commercial towers, malls, shopping centres, and luxury hotels. The organization concentrated on large-scale commercial-residential projects to finance the project instead of providing affordable housing, educational and medical services, or public spaces. Figure 4 shows the shortage of facilities and public services at the local level in the Samen district. Interviews with pilgrims revealed that these large-scale commercial-residential centres are only suitable for wealthy pilgrims and have impeded access to affordable services and facilities for ordinary pilgrims. "In the past, we used to stay in local residents' houses. They were not good quality, but they were very affordable for low-income pilgrims. Now these houses have been destroyed and luxury hotels have been built that most pilgrims cannot afford to stay in" (39-year-old male pilgrim).

\subsection{Sociocultural impacts}

Quality of life is deeply affected by feelings of anomie, and anomic people tend to have lower life satisfaction (Genov, 1998; Western \& Lanyon, 1999; Huschka \& Mau, 2005). Crimes such as drug and alcohol trafficking, extortion, harassment, and prostitution can significantly reduce the quality of life in urban neighbourhoods. On the other hand, the entry of strangers into residential neighbourhoods without adequate supervision can not only increase criminal activities but also significantly reduce life satisfaction (Huppert et al., 2009; Hanson et al., 2010; Kitchen \& Williams, 2010). Altogether, $77.3 \%$ of the respondents were somewhat or completely dissatisfied with the incidence of crime in their neighbourhoods, and $73.9 \%$ were somewhat or completely dissatisfied with the entrance of strangers into their personal living area. The 2016 Report on crime prevention and community safety in Mashhad indicates a concentration of crime hotspots in the Samen district (Figure 5). In addition, an examination of the number of defendants held in the Mashhad Central Prison shows that 


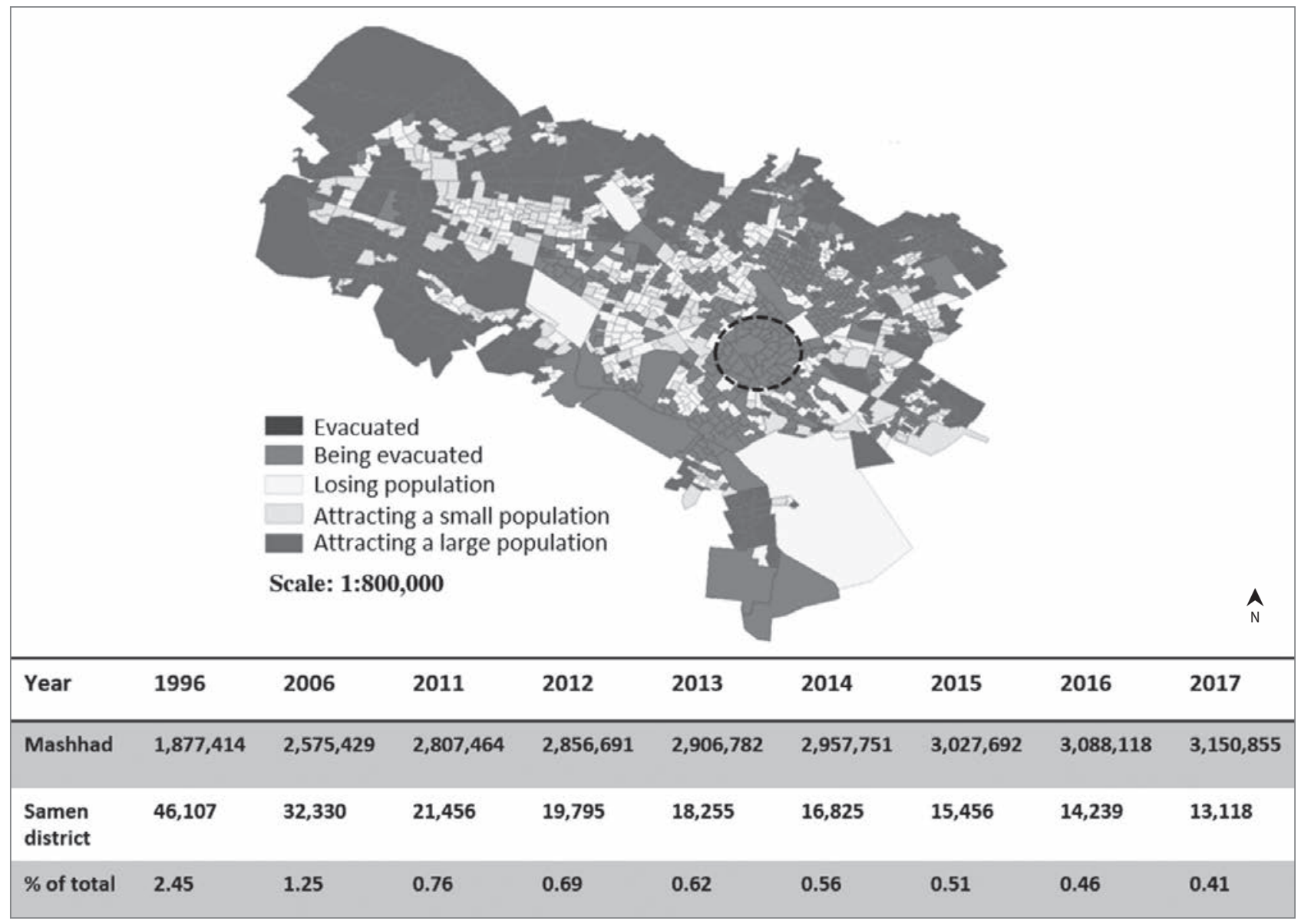

Figure 6: Population change in Mashhad (source: Mashhad Municipality, 2017).

the Samen district ranks first in crimes against public decency and morality, fraud, and crimes against people and property. Moreover, the district ranks second in other crimes, such as drug abuse, theft, and drug trafficking in the city (Mashhad Police Department, 2016). In addition to undesirable socioeconomic circumstances in the district, lack of planning for unsafe spaces (corners and L- and U-shaped spaces) and desolate properties resulting from the widespread demolition by the project have significantly contributed to crime. Interviews also show that the presence of strangers has considerably increased due to the uncontrolled increase in the number of hotels and hostels built based on the project recommendations. Due to the degradation of neighbourhood quality, old residents have started leaving their houses and illegally renting them out to tourists and pilgrims. Official statistics show that in the Samen district there are currently 3,300 private houses illegally used for pilgrims' accommodation (City Council of Mashhad, 2016).

The Samen district has undergone a significant population loss over the past two decades; it is currently considered a shrinking district that is being evacuated by its residents (Figure 6). The interviewees believed that social interactions were significant before the project, and that relatives lived in the same neighbourhoods. Following the displacement of old residents, traditional social relations in these neighbourhoods have greatly declined. Due to the low quality of the district, new inhabitants are often from the poor migrant class. The Samen district is currently the second most popular destination for non-Iranian immigrants in Mashhad (City Council of Mashhad, 2016). As a result, the ethnic and cultural harmony of the district has declined significantly, and more than half of the respondents were somewhat or completely dissatisfied with the quality of social interactions and the ethnic and cultural harmony of their neighbourhood.

\subsection{Economic impacts}

Livelihood not only has a direct impact on subjective quality of life, but it is also an important factor in residents' ability to participate in renovation (Ashley \& Carney, 1999; Karl, 2000). The income level of residents in the Samen district is directly related to their employment and economic assets such as land and property (Saghatoleslami, 2017; Kafashpor et al., 2018). Although the shrine has made the Samen district one of the most profitable tourist attractions in Iran, less than 5\% of the 
respondents were somewhat or completely satisfied with their income level and economic assets. The residents believed that before the project the main occupation of residents was tourist-related, such as selling products to tourists, souvenir shops, and renting houses to pilgrims and tourists. However, local retail has been heavily affected by the large shopping centres and malls in the project. The decree prohibited private construction and renovation, leading to a significant decline in residents' income from renting their houses. Locals believed the neighbourhood used to be a source of income for residents, but the project damaged their jobs and income. "After the project, many properties were destroyed and replaced by upscale malls and shopping centres. Most of our customers were attracted to these centres. We could not compete, so we lost our customers and had no choice but to close the shop" (31-year-old male shopkeeper).

The interviews with real estate agencies also show that the project has reduced local residents' property values. Local people were prohibited from selling their properties unless it was to the Samen Renewal Organization. However, the prices set by the organization differed greatly from the real value of the properties on the regular housing market. The long duration of the project has had a diminishing impact on the value of local properties. "We had to sell off our properties cheaply, otherwise the organization would cut off our electricity, gas, and drinking water. The increase in value was only for largescale commercial properties owned by investors, not for the local properties" (43-year-old female resident).

\section{Discussion}

Urban decay in Iran has no single cause; it has resulted from various interrelated socioeconomic conditions and urban planning policies over the past decades, such as lack of attention to infill development and public-private partnerships (Sarkheyli et al., 2016; Abrahamian, 2018). Although the Samen Renewal Project sought to improve residents' quality of life and the performance and competitiveness of the tourism industry, this large-scale project had undesirable physical, sociocultural, and economic impacts.

Since the inception of the project, a lack of sustainable and stable financial resources turned into serious challenges for the municipality and the Samen Renewal Organization to implement this large-scale transformation project. Due to the financial sanctions imposed on Iran after the Iran-Iraq War in 1979, the national government introduced a new financial system for municipalities in Iran (Sarkheyli et al., 2016; Gholizadeh \& Aminirad, 2018). This new legislation cut off much state support for municipalities without identifying any alternative economic sources. Based on this policy, the national government refused to allocate funds to the Samen Renewal Project, and the organization was forced to fund the project through self-sufficient and zero-based budgeting. Similar to urban renewal projects in contexts such as Taiwan (Hsu \& Chang, 2013), China (Chen, 2013), and Canada (Zuberi \& Taylor, 2013), the financing pattern of the Samen Renewal Project changed the initial goals of the project to the goals of investors and private developers. However, as Cullingworth et al. (2013) mentioned, private developers are not usually interested in low-income housing (whether subsidized or not), but in developing shopping and commercial centres. Thus, the municipality and the Samen Renewal Organization considered developing the tourism industry to be the main goal of the project to attract investors and private developers in Mashhad's central district. The organization subsequently applied fundamental changes in the initial land-use plan to address the interests of investors and private developers and ultimately generate revenue for the project by increasing the density of commercial land use.

The authorities sought to acquire land and property through compulsory purchase orders. Like several other high-profile renewal projects - for example, London's Docklands scheme and Sheffield's Lower Don Valley (Imrie \& Thomas, 1997) the use of compulsory purchase orders in the Samen district was also characterized by opposition, dissent, and general hostility from those affected. Similar to several examples in the United States (Teaford, 2000), lower-income groups in the Samen district were displaced through exercise of eminent domain, and then transport infrastructure, shopping malls, luxury apartment buildings, and hotels took their place. In addition, opposition by local residents and shopkeepers has significantly prolonged the process, so that the project has only been about $50 \%$ realized after twenty-five years.

The findings of this article are in line with assessment of gentrification and urban renewal Canada (Zuberi \& Taylor, 2013) and Turkey (Güzey, 2013), where neo-liberal renewal policies and growing reliance on the private sector has led to a declining commitment to the public good and the needs of local residents, favouring instead the interests of private developers. The capitalist approach has not only marginalized the social goals and needs of local residents in residential neighbourhoods around the shrine, but has also diminished residents' quality of life due to undesirable physical, sociocultural, and economic consequences. The social tensions from ongoing dislocation and economic strain will continue to challenge the urban planners and policymakers of the Samen Renewal Project to maintain a balance between the needs of residents, tourists, and private developers. 


\section{Conclusion}

The Samen Renewal Project has physically intervened in the central district of Mashhad by adopting a non-cooperative planning and capitalist approach to the residential neighbourhoods around the Imam Reza shrine. The results show that this intervention had undesirable physical, sociocultural, and economic impacts on these residential neighbourhoods. On average, $68 \%$ of the respondents in the Samen district were somewhat or completely dissatisfied with accessibility, $71.4 \%$ with spatial structure, $71.6 \%$ with the land-use pattern, $75.6 \%$ with social order, $54.8 \%$ with social cohesion, and $80.2 \%$ with their livelihood. These undesirable effects significantly reduce the quality of life in the study area. The residents scored their quality of life at 3.21 on a scale ranging from 1 to 10 . Furthermore, the physical arrangement of the neighbourhoods has the strongest correlation with the subjective quality of life in the study area $(r=0.755)$.

In conclusion, the Samen Renewal Project has seriously deviated from its initial goals of renovation toward the goals of investors and private developers. This has happened due to a lack of sustainable project financing. As a result, the capitalist vision ignored the needs of locals, and instead favoured the interests of tourists, pilgrims, and especially private developers. It should be emphasized that what can be seen in the Samen district is not only a mistake in the formulation and implementation of the project, but could be related to the oil-based political economy of Iran, in which the influx of oil money leads to property price inflation and oil-led gentrification, and thus all parts of the government and urban management seek to leverage the rent gap and extract greater financial benefits from urban renewal projects. Thus, future studies need to better understand the dynamics of transformation and gentrification in urban renewal projects in the developing world, particularly in countries with an oil-based economy, and provide strategies and policies to maintain balance between residents' quality of life, the needs of tourists, and the interests of the investors. The results also suggest that urban planners and policymakers should envision a more diverse, inclusive, and socially sustainable future for urban renewal projects, and they highlight the need for new mechanisms to counter trends of growing social exclusion, displacement, and disenfranchisement during project implementation.

Navid Forouhar, Islamic Azad University of Mashhad, School of Architecture and Art, Mashhad, Iran

E-mail: navidforouhar@mshdiau.ac.ir

Amir Forouhar, Art University of Isfahan, Faculty of Architecture and Urban Planning, Isfahan, Iran

E-mail: a.forouhar@aui.ac.ir

\section{References}

Abrahamian, E. (2018) A history of modern Iran. Cambridge, Cambridge University Press.

Andersen, H. S. (2019) Urban sores: On the interaction between segregation, urban decay and deprived neighbourhoods. London, Routledge. DOI: $10.4324 / 9781315191980$

Ashley, C. \& Carney, D. (1999) Sustainable livelihoods: Lessons from early experience. London, Department for International Development.

Atkinson, R. (2000) The hidden costs of gentrification: Displacement in central London. Journal of Housing and the Built Environment, 15(4), pp. 307-326.

Bacqué, M. H., Fijalkow, Y., Launay, L. \& Vermeersch, S. (2011) Social mix policies in Paris: Discourses, policies and social effects. International Journal of Urban and Regional Research, 35(2), pp. 256-273. DOI: $10.1111 /$ j.1468-2427.2010.00995.x

Bianchini, F. \& Parkinson, M. (1994) Cultural policy and urban regeneration: The west European experience. Manchester, Manchester University Press.

Bielderman, A., de Greef, M. H. G., Krijnen, W. P. \& van der Schans, C. P. (2015) Relationship between socioeconomic status and quality of life in older adults: A path analysis. Quality of Life Research, 24(7), pp. 16971705. DOI: 10.1007/s11136-014-0898-y

Bigio, A. G. \& Licciardi, G. (2010) The urban rehabilitation of Medinas: The World Bank experience in the Middle East and North Africa. (= Urban Development Series Knowledge Papers 54935). Washington, DC, World Bank.

Carnahan, D., Gove, W. \& Galle, O. R. (1974) Urbanization, population density, and overcrowding: Trends in the quality of life in urban America. Social Forces, 53(1), pp. 62-72. DOI: 10.1093/sf/53.1.62

Catley, A., Burns, J., Abebe, D. \& Suji, O. (2014) Participatory impact assessment: A design guide. Somerville, MA, Tufts University. Available at: https://fic.tufts.edu/wp-content/uploads/PIA-guide_revised-2014-3. pdf (accessed 20 Aug. 2020).

Chen, Y. (2013) Neoliberal-inspired large-scale urban development projects in Chinese cities. In: Leary, M. E. \& McCarthy, J. (eds.) The Routledge companion to urban regeneration, pp. 97-107. London, Routledge.

City Council of Mashhad (2016) Report on the residents' problems of the central fabric of Mashhad (2016). Mashhad, Iran.

Costanza, R., Fisher, B., Ali, S., Beer, C., Bond, L., Boumans, R., et al. (2007) Quality of life: An approach integrating opportunities, human needs, and subjective well-being. Ecological Economics, 61(2-3), pp. 267-276. DOI: 10.1016/j.ecolecon.2006.02.023

Cramer, V., Torgersen, S. \& Kringlen, E. (2004) Quality of life in a city: The effect of population density. Social Indicators Research, 69(1), pp. 103-116. DOI: 10.1023/b:soci.0000032663.59079.0b

Creswell, J. W. (1999): Mixed-method research: Introduction and application. In: Cizek, G. J. (ed.) Handbook of educational policy, pp. 455-472. San Diego, Academic Press. DOI: 10.1016/b978-012174698-8/50045-x

Cullingworth, B., Caves, R. W., Cullingworth, J. B. \& Caves, R. (2013) Planning in the USA: Policies, issues, and processes. London, Routledge. DOI: 0.4324/9780203126561

Cummins, R. A. (1996) The domains of quality of life: An attempt to order the chaos. Social Indicators Research, 38, pp. 303-328.

Dale, O. J. (1999) Urban planning in Singapore: The transformation of a city. New York, Oxford University Press. 
Day, R. L. (1987) Relationships between life satisfaction and consumer satisfaction. Marketing and the quality of life interface. New York, Quorum Books.

Deller, S. C., Tsai, T. H., Marcouiller, D. W. \& English, D. B. K. (2001) The role of amenities and quality of life in rural economic growth. American Journal of Agricultural Economics, 83(2), pp. 352-365. DOI: 10.1111/0002-9092.00161

Deng, C. \& Ma, J. (2015) Viewing urban decay from the sky: A multi-scale analysis of residential vacancy in a shrinking US city. Landscape and Urban Planning, 141, pp. 88-99.

DOI: 10.1016/j.landurbplan.2015.05.002

El Din, H. S., Shalaby, A., Farouh, H. E. \& Elariane, S. A. (2013) Principles of urban quality of life for a neighborhood. HBRC Journal, 9(1), pp. 8692. DOI: 10.1016/j.hbrcj.2013.02.007

Forouhar, A. (2016) Estimating the impact of metro rail stations on residential property values: Evidence from Tehran. Public Transport, 8(3), pp. 427-451. DOI: 10.1007/s12469-016-0144-9

Forouhar, A. \& Hasankhani, M. (2018) The effect of Tehran metro rail system on residential property values: A comparative analysis between high-income and low-income neighbourhoods. Urban Studies, 55(16), pp. 3503-3524. DOI: $10.1177 / 0042098017753089$

Forouhar, N. \& Forouhar, A. (2020) Evaluating the role of urban planners in participatory urban planning: A conceptual model of success in Iran. Archives of Business Administration and Management, 3, pp. 135. DOI: $10.29011 / 2642-3243.100135$

Genov, N. (1998) Transformation and anomie: Problems of quality of life in Bulgaria. Social Indicators Research, 43(1-2), pp. 197-209.

Gholizadeh, A. A. \& Aminirad, M. (2018) Determining the optimal structure of Tehran municipality income basis based on risk and returns. Journal of Urban Economics and Management, 6(23), pp. 81-95.

Güzey, Ö. (2013) Evaluation of urban regeneration as a government-assisted revenue strategy in Turkey: The global imperative. In: Leary, M.

E. \& McCarthy, J. (eds.) The Routledge companion to urban regeneration, pp. 86-96. London, Routledge.

Hanson, R. F., Sawyer, G. K., Begle, A. M. \& Hubel, G. S. (2010) The impact of crime victimization on quality of life. Journal of Traumatic Stress, 23(2), pp. 189-197. DOI: 10.1002/jts.20508

Hosseyni, S. J. (2008) Constant public association in reconstruction and development of urban distressed areas. Mashhad, Iran, Sokhan Gostar.

Hsu, J.-Y. \& Chang, W.-H. (2013) From state-led to developer-led? The dynamics of urban renewal policies in Taiwan. In: Leary, M. E. \& McCarthy, J. (eds.) The Routledge companion to urban regeneration, pp. 168178. London, Routledge.

Huppert, F. A., Marks, N., Clark, A., Siegrist, J., Stutzer, A., Vittersø, J., et al. (2009) Measuring well-being across Europe: Description of the ESS well-being module and preliminary findings. Social Indicators Research, 91(3), pp. 301-315. DOI: 10.1007/s11205-008-9346-0

Huschka, D. \& Mau, S. (2005) Aspects of quality of life: Social anomie in South Africa. Discussion Papers / Wissenschaftszentrum Berlin für Sozialforschung, 2005(2).

Ibem, E. O. (2013) Bad memories and good prospects for housing-led urban regeneration projects in Nigeria. In: Leary, M. E. \& McCarthy, J. (eds.) The Routledge companion to urban regeneration, pp. 361-370. London, Routledge.

Imrie, R. \& Thomas, H. (1997) Law, legal struggles and urban regeneration: Rethinking the relationships. Urban Studies, 34(9), pp. 1401-1418. DOI: 10.1080/0042098975484
Johansson, S. (2002) Conceptualizing and measuring quality of life for national policy. In: Hagerty, M. R., Vogel, J. \& Moeller, V. (eds) Assessing quality of life and living conditions to guide national policy: The state of the art, pp. 13-32. Dordrecht, Springer.

Kafashpor, A., Ghasempour Ganji, S. F., Sadeghian, S. \& Johnson, L. W. (2018) Perception of tourism development and subjective happiness of residents in Mashhad, Iran. Asia Pacific Journal of Tourism Research, 23(6), pp. 521-531. DOI: 10.1080/10941665.2018.1476392

Karl, M. (2000) Monitoring and evaluating stakeholder participation in agriculture and rural development projects: A literature review. Rome, Sustainable Development Department (SD), Food and Agriculture Organization of the United Nations (FAO).

Kheyroddin, R., Taghvaee, A. \& Forouhar, A. (2014) The influence of metro station development on neighbourhood quality. International Review for Spatial Planning and Sustainable Development, 2(2), pp. 64-75. DOI: 10.14246/irspsd.2.2_64

Kitchen, P. \& Williams, A. (2010) Quality of life and perceptions of crime in Saskatoon, Canada. Social Indicators Research, 95(1), pp. 33-61. DOI: $10.1007 /$ s11205-009-9449-2

Leary, M. E. \& McCarthy, J. (2013) Introduction: Urban regeneration, a global phenomenon. In: Leary, M. E. \& McCarthy, J. (eds.) The Routledge companion to urban regeneration, pp. 21-34. London, Routledge.

Lee, Y.-J. (2008) Subjective quality of life measurement in Taipei. Building and Environment, 43(7), pp. 1205-1215.

DOI: 10.1016/j.buildenv.2006.11.023

Li, G. \& Weng, Q. (2007) Measuring the quality of life in city of Indianapolis by integration of remote sensing and census data. International Journal of Remote Sensing, 28(2), pp. 249-267. DOI: 10.1080/01431160600735624

Lo, C. P. \& Faber, B. J. (1997) Integration of Landsat Thematic Mapper and census data for quality of life assessment. Remote Sensing of Environment, 62(2), pp. 143-157. DOI: 10.1016/s0034-4257(97)00088-6

Map data (2020) Available at: https://www.google.com/maps/search/ samen+district+mashhad/@36.2882319,59.6137988,1802m/ data=!3m1!1e3 (accessed 24 Sept 2020).

Marans, R. W. \& Stimson, R. J. (2011) Investigating quality of urban life: Theory, methods, and empirical research (= Social Indicators Research Series 45). Dordrecht, Springer Science \& Business Media. DOI: 10.1007/978-94-007-1742-8

Marra, G., Barosio, M., Eynard, E., Marietta, C., Tabasso, M. \& Melis, G. (2016) From urban renewal to urban regeneration: Classification criteria for urban interventions. Turin 1995-2015: Evolution of planning tools and approaches. Journal of Urban Regeneration \& Renewal, 9(4), pp. 367-380.

Mashhad Municipality Planning and Urban Development Department (2017) Statistical Yearbook of Mashhad. Mashhad. Available at: https://mspl.mashhad.ir/parameters/mashhad/modules/cdk/ upload/content/portal_content/File/92/Year\%201396/Final_Amarnameh_1395-96-8-27_Part1.pdf (accessed 31 Jul. 2020).

Mashhad Police Department (2016) Report on Crime Prevention and Community Safety in Mashhad. Mashhad.

McCarthy, J. (2007) Partnership, collaborative planning and urban regeneration. Chesterfield, UK, Ashgate Publishing, Ltd.

McCormick, K., Anderberg, S., Coenen, L. \& Neij, L. (2013) Advancing sustainable urban transformation. Journal of Cleaner Production, 50, pp. 1-11. DOI: 10.1016/j.jclepro.2013.01.003 
Mielck, A., Vogelmann, M. \& Leidl, R. (2014) Health-related quality of life and socioeconomic status: Inequalities among adults with a chronic disease. Health and Quality of Life Outcomes, 12(1), pp. 1-10. DOI: 10.1186/1477-7525-12-58

Morris, J. B., Tassone, V., De Groot, R., Camilleri, M. \& Moncada, S. (2011) A framework for participatory impact assessment: Involving stakeholders in European policy making, a case study of land use change in Malta. Ecology and Society, 16(1), article 12. DOI: 10.5751/es-03857-160112

Munoth, N., Jain, R. K., Raheja, G. \& Brar, T. S. (2013) Issues of sustainable redevelopment of city core: A study of developed and developing countries. Journal of The Institution of Engineers (India), Series A, 94(2), pp. 117-122. DOI: 10.1007/s40030-013-0045-8

Musschenga, A. W. (1997) The relation between concepts of quality-of-life, health and happiness. The Journal of Medicine and Philosophy, 22(1), pp. 11-28. DOl: 10.1093/jmp/22.1.11

$\mathrm{Ng}$, M. K. (2005) Quality of life perceptions and directions for urban regeneration in Hong Kong. In: Shek, D. T., Chan, Y. K. \& Lee, P. S. (eds.) Quality-of-life research in Chinese, western and global contexts (= Social Indicators Research Series 25), pp. 441-465. Dordrecht, Springer. DOI: 10.1007/1-4020-3602-7_15

Rabbani, G., Shafaqi, S. \& Rahnama, M. R. (2018) Urban sprawl modeling using statistical approach in Mashhad, northeastern Iran. Modeling Earth Systems and Environment, 4(1), pp. 141-149.

DOI: 0.1007/s40808-017-0404-y

Roberts, P., Sykes, H. \& Granger, R. (2016) Urban regeneration. London, Sage.

Roche, C. J. (1999) Impact assessment for development agencies: Learning to value change. Oxford, Oxfam.

Rokicka, E. \& Petelewicz, M. (2014) Subjective quality of life and socio-economic status. The case of Lodz inhabitants. Przegląd Socjologiczny, 63(2), pp. 143-161.

Saghatoleslami, A. (2017) Study on contemporary interventions in the historical fabric of Mashhad. Creative City Design, 1(2), pp. 28-42.

Samen Renewal Organization (2002) Report on the Samen Renewal Project. Mashhad, Iran.

Sarkheyli, E., Rafieian, M. \& Taghvaee, A. A. (2016) Qualitative sustainability assessment of the large-scale redevelopment plan in Samen district of Mashhad. International Journal of Architecture and Urban Development, 6(2), pp. 49-58.

Seik, F. T. (2001) Quality of life in cities. Cities, 1(18), pp. 1-2.

Tallon, A. (2013) Urban regeneration in the UK. London, Routledge.

Teaford, J. C. (2000) Urban renewal and its aftermath. Housing Policy Debate, 11(2), pp. 443-465. DOI: 10.1080/10511482.2000.9521373

von Hoffman, A. (2008) The lost history of urban renewal. Journal of Urbanism, 1(3), pp. 281-301.

Western, J. \& Lanyon, A. (1999) Anomie in the Asia Pacific region: The Australian study. In: Atteslander P., Gransow B. \& Western J. (eds.) Comparative anomie research. Hidden barriers-hidden potential for social development, pp. 73-98. Ashgate, Aldershot. DOI: $10.4324 / 9781315196046-5$

Zuberi, D. \& Taylor, A. (2013) Urban renewal in Vancouver, Canada. In: Leary, M. E. \& McCarthy, J. (eds.) The Routledge companion to urban regeneration, pp. 312-322. London, Routledge. 